\title{
Peripheral venous access using devices over needles with and without extension: costs and outcomes
}

\author{
Acesso venoso periférico utilizando dispositivos sobre agulha com e sem extensão: custos e desfechos \\ Acceso venoso periférico utilizando dispositivos de aguja con y sin extensión: costos y resultados
}

Antônio Fernandes Costa Lima'
ORCID: 0000-0002-3582-2640
Amanda Saba'
ORCID: 0000-0002-1438-3917
Abílio Gonçalves das Neves Filho'
ORCID: 0000-0001-9008-0873
Karen Aparecida Couto'
ORCID: 0000-0003-0832-7449
Luciana Oliveira e Silva"
ORCID: 0000-0003-3882-3646

'Universidade de São Paulo. São Paulo, São Paulo, Brazil. "Universidade Federal de São Paulo. São Paulo, São Paulo, Brazil.

How to cite this article: Lima AFC, Saba A, Neves Filho AG, Couto KA, Silva LO. Peripheral venous access using devices over needles with and without extension: costs and outcomes. Rev Bras Enferm. 2020;73(5):e20180921. doi: http://dx.doi.org/10.1590/0034-7167-2018-0921

Corresponding author: Antônio Fernandes Costa Lima E-mail: tonifer@usp.br

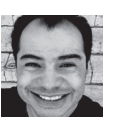

EDITOR IN CHIEF: Antonio José de Almeida Filho ASSOCIATE EDITOR: Andrea Bernardes

Submission: 03-08-2019 Approval: 10-18-2019

\begin{abstract}
Objectives: to analyze the mean direct cost and peripheral venous access length outcomes using devices over needle with and without extension. Methods: quantitative, exploratorydescriptive research. Venous punctures and length of the devices were followed. The mean direct cost was calculated by multiplying the time (timed) spent by nursing professionals by the unit cost of labor, adding to the cost of materials. Results: the total mean direct cost of using devices "with extension" (US\$ 9.37) was 2.9 times the cost of using devices "without extension" (US\$ 4.50), US\$ 7.71 and US\$2.66, respectively. Totaling 96 hours of stay, the "device over needle with extension" showed a lower occurrence of accidental loss. Conclusions: the use of the "device over needle with extension", despite its higher mean direct cost, was more effective in favoring adequate length of peripheral venous access. Descriptors: Vascular Access Devices; Medical-Surgical Nursing; Nursing Care; Costs and Cost Analysis; Cost Control.
\end{abstract}

\section{RESUMO}

Objetivos: analisar o custo direto médio e os desfechos de permanência de acesso venoso periférico, utilizando dispositivos sobre agulha com e sem extensão. Métodos: pesquisa quantitativa, exploratório-descritiva. Acompanharam-se as punções venosas e o tempo de permanência dos dispositivos. Calculou-se o custo direto médio multiplicando-se o tempo (cronometrado) despendido por profissionais de enfermagem pelo custo unitário da mão de obra, somando-se ao custo dos materiais. Resultados: o custo direto médio total do uso de dispositivo "com extensão" (US\$ 9,37) foi 2,9 vezes do que o custo do uso de dispositivo "sem extensão" (US\$ 4,50), destacando-se os custos dos materiais, US\$ 7,71 e US\$2,66, respectivamente. Totalizando 96 horas de permanência, o "dispositivo sobre agulha com extensão" apresentou menor ocorrência de perda acidental. Conclusões: o uso do "dispositivo sobre agulha com extensão", apesar do maior custo direto médio, foi mais eficaz para favorecer o adequado tempo de permanência do acesso venoso periférico. Descritores: Dispositivos de Acesso Vascular; Enfermagem Médico-Cirúrgica; Cuidados de Enfermagem; Custos e Análise de Custo; Controle de Custos.

\section{RESUMEN}

Objetivos: analizar el costo directo promedio y los resultados de permanencia del acceso venoso periférico, utilizando dispositivos de aguja con y sin extensión. Métodos: investigación cuantitativa, exploratoria descriptiva. Se siguieron los pinchazos venosos y el tiempo de permanencia de los dispositivos. El costo directo promedio se calculó multiplicando el tiempo (cronometrado) dedicado por los profesionales de enfermería por el costo unitario de la mano de obra, lo que se suma al costo de los materiales. Resultados: el costo directo promedio total de usar dispositivos "extendidos" (US\$ 9,37) fue 2,9 veces el costo de usar dispositivos "no extendidos" (US\$ 4,50) de materiales, US\$7.71 y US\$2.66, respectivamente. Con un total de 96 horas de estadía, el "dispositivo de aguja extendida" mostró una menor ocurrencia de pérdida accidental. Conclusiones: a pesar del costo directo promedio más alto, el uso de un "dispositivo de aguja extendida" fue más efectivo para favorecer un tiempo de acceso venoso periférico adecuado.

Descriptores: Dispositivos de Acceso Vascular; Enfermería Médico-Quirúrgica; Cuidado de Enfermería; Costos y Análisis de Costos; Control de Costos. 


\section{INTRODUCTION}

In health institutions, peripheral venipuncture is an invasive procedure commonly performed by nursing professionals ${ }^{(1)}$ to establish a vascular access that enables the recommended intravenous therapy (IVT).

Different types of catheter devices over needle with and without extension are commercially available for peripheral venous access (PVA) installation. According to the Brazilian National Health Surveillance Agency (ANVISA - Agência Nacional de Vigilância Sanitária), polyurethane composite devices have a lower complication rate when compared to polyvinyl or polyethylene devices ${ }^{(2)}$. Both have a safety system to prevent work accidents.

The catheter device over needle with extension has an integrated two-way vinyl extension. This device without extension must be connected to a two- or four-way vinyl extension or a three-way structure commonly referred to in assistive practice as a "tap". Due to its peculiar characteristics, the device with extension has a higher price, which may interfere with its acquisition and restrict its indication, in different care contexts, especially in public organizations that usually need to manage scarce resources.

Knowing the costs associated with a given procedure contributes to the rational allocation of resources ${ }^{(3)}$ to ensure the improvement of safety and quality of care in balance with limited financial resources. In this perspective, the price of the device without extension is lower. However, there is a need to determine, in addition to the unit value of the device, the cost related to the time spent by the nursing professional and the costs of other materials consumed to estimate, more accurately, the cost of installing a PVA associated with the use of one or another type of intravascular device. Such knowledge will provide evidence of financial aspects of the microeconomic dimension and, consequently, subsidize proper cost management. However, it is relevant, besides the financial aspects, also to verify the outcomes associated with the different types of intravascular devices.

Regarding the outcome of a PVA length time, the Center Diseases Control (CDC) recommends between 72 and 96 hours $^{(4)}$. In Brazil, ANVISA recommends the length of a PVA for up to 96 hour ${ }^{(2)}$, which can be extended according to the institution's best practices and if clinically indicated.

PVA may be removed in advance in the presence of any complications ${ }^{(2,5)}$, such as phlebitis, leakage, infiltration or accidentally. To prevent the occurrence of complications, which can generate tangible costs for health organizations and intangible costs for patients, it is essential that health professionals adopt practices based on the best scientific evidence for the insertion and handling of $\mathrm{PVA}^{(2,4)}$.

When comparing two devices classified as open system (which needed to be connected to an extension) and closed system (which had an integrated extension), a study observed that although there was a better insertion of the open system, since the nursing staff had more experience with this type of device, the closed system presented lower complication rates( ${ }^{(6)}$.

A randomized clinical trial comparing complications associated with a needle-free and vinyl-extension device found complications in $55 \%$ of the punctures, of which $18 \%$ corresponded to phlebitis, $11 \%$ to infiltration, $11 \%$ to obstruction and $9 \%$ to traction. The device without extension had a mean length of stay of 3.73 days and the device with extension coupled 3.28 days. There was a significant difference in insertion success that was greater in the device over needle without extension ${ }^{(1)}$.

Considering that PVA installation requires the consumption of human and material resources, generating costs that need to be identified and properly managed, as well as the knowledge of the outcomes related to the devices used, this study was conducted.

\section{OBJECTIVES}

To analyze the mean direct cost and peripheral venous access length outcomes using device over needles with and without extension.

\section{METHODS}

\section{Ethical aspects}

All guidelines and regulatory standards for research involving human subjects have been met. The Research Ethics Committee of Hospital Público de Ensino e Pesquisa (HPEP - Public Teaching and Research Hospital) field of study (Opinion 1,889,725) approved the project.

\section{Design, period and place of study}

This is a quantitative, exploratory and descriptive study performed in the medical clinic ward of an HPEP, which has 49 beds for hospitalization of adult and elderly patients coming from the Clinical Clinic, Emergency Room or Intensive Care Units. The hospitalization of these patients aims to compensate for underlying diseases such as Diabetes Mellitus (DM) and Hypertension, and/ or clinical investigation of signs and symptoms.

During the study, during the typical nine months of hospitalizations in the medical clinic ward, in the morning there were four assisting nurses and ten nursing technicians ( 7 a.m. to 1 p.m.). In the afternoon there were two nurses and eight technicians (1 p.m. to 7 p.m.), and two nurses and eight technicians in each night shift (even and odd -7 p.m. to 7 a.m.).

\section{Population or sample; inclusion and exclusion criteria}

The sample calculation was performed using the G Power software, using the analysis of variance test (ANOVA) to compare two independent groups, considering $\alpha=0.05, \beta=0.85$ and an effect size of 0.30 . Thus, 128 patients with PVA indication to be observed were established, being 64 group members using "device over needle extension" and 64 group using "device over needle without extension".

Nurses and nursing technicians who had at least one year of professional experience, therefore experienced in PVA establishment, and patients who required PVA for antibiotic therapy, analgesia or electrolyte replacement, and who had no compromised venous network, were included in the study. Patients with generalized edema and indication of central venous catheter or peripherally inserted central catheter were excluded. 


\section{Study protocol}

Data were collected from January to September 2017. Initially, all nursing professionals were observed while performing peripheral venipuncture procedures and it was found that they adequately met the five standard steps in HPEP: 1) separation of materials; 2 ) explanation of the procedure to the patient; 3 ) venous network evaluation; 4) puncture; and 5) nursing notes regarding PVA establishment. All professionals and invited patients agreed to participate in the study by signing the Informed Consent Form.

Subsequently, non-participant observations were carried out for documentation, in an instrument containing fields intended to record the quantity and category of nursing professionals involved. Also, time (timed) spent in the above five steps (considering the start and end of each); materials and quantities used; punctured limb; type of device over needle and daily evaluation of the device insertion site, up to 96 hours of stay, in order to highlight the respective clinical outcomes.

In HPEP, there is no standardization of the type of device to be used, and this decision is the responsibility of the performing professional, based on their clinical experience. It was observed that mid-level professionals, when in doubt regarding the device of choice, reported to the nurse of the medical clinic ward. It was found that by prescribing hemotherapics, which require smaller gauge device and greater lumen due to blood viscosity, professionals opted for the device without extension. Facing elderly patients and/or with a weaker venous network, they opted for the device with extension.

In order to obtain the mean direct cost of the procedure $\left[\overline{C\left(P_{i}\right)}\right]$ with the use of devices over needles with and without extension, a micro-costing study was used whose reference consisted of the direct costs defined as a monetary expenditure. It can be identified and clearly quantified, applied in the production of a product or service where it can be associated with the product or department ${ }^{(7)}$. In direct cost studies, the objective measure of consumption is the materials, medicines and/or solutions used and the direct labor (DL) involved in the procedure or process ${ }^{(8)}$.

DL refers to staff who work directly on a product/service provided as long as it is possible to measure the time spent and identify who performed the work. It consists of salaries, social charges, vacation provisions and $13^{\text {th }}$ month pay ${ }^{(7)}$.

$\mathrm{DL}$ unit cost was calculated from the mean salaries provided by the HPEP Human Resources Service. The amounts, in reais ( $R \$$ ), were converted to the US dollar (US\$) at the conversion rate of US\$ 0.3 R\$, based on the quotation on May 31, 2017 provided by the Central Bank of Brazil. Most professionals worked 30 hours a week. The cost was US\$2,142.34 (compensation/120 hours), US\$ 17.85 (compensation/hour) and US\$ 0.30 (compensation/ minute) for nurses and US\$1,092.26 (compensation/120 hours), US\$ 9.15 (compensation/hour) and US\$ 0.15 (compensation/ minute) for nursing technicians.

For the determination of $\overline{C\left(P_{i}\right)}$, mean amount of materials $\left[\overline{q m_{k}}\right]$; mean unit price of each material $\left[\overline{p m u_{k}}\right]$; mean time spent in each professional category $\left[\bar{t}_{c}\right]$ and mean unit wage bill of each professional category $\left[\overline{S u_{c}}\right]$ were identified. The equation was obtained: $\left.\overline{C\left(P_{i}\right)}=\sum_{k=1}^{n} \overline{\left(q_{k}\right.} \cdot \overline{P u_{k}}\right)+\sum_{c=1}^{n} \overline{\left(t_{c}\right.} \cdot \overline{\left.S u_{c}\right)^{(9)}}$.

\section{Analysis of results, and statistics}

Continuous variables were described by mean, standard deviation, minimum and maximum values. Mann Whitney test was used to compare continuous data between groups and Pearson's Chi-square test $\left(\mathrm{X}^{2}\right) /$ Fisher was used to compare categorical variables. The significance level of $a \leq 0.05$ was considered. SPSS software version 21.0 was used.

\section{RESULTS}

Seventeen nursing professionals were followed during the installation of PVA. Most were nursing technicians (82.35\%), aged 27-55 years old, mean 41 (SD=9.27), nursing experience time of four to 30 years, mean $14(S D=7.84)$ and mean time in the medical clinic ward of four years $(S D=2.17)$, ranging from one to ten years.

Among the 128 patients observed and evaluated for PVA insertion site, until completing 96 hours of stay in the "device over needle with extension" group $(n=64)$, the mean age was 52 years $(S D=18.81)$. There was a variation of $19-83$ years and in the "without extension" group $(n=64)$ the mean age was 54 years $(S D=14.66)$, ranging from $22-90$ years. In both groups, female patients equally prevailed $(54.67 \%)$.

According to Table 1, in both groups, the most prevalent medical diagnostic hypotheses were hypertension and DM. Antibiotics and analgesics administration corresponded to the most frequent reasons for PVA indication. Puncture attempts ranged from one to two in the "device over needle with extension" group and one to three in the "without extension" group, with success in the first puncture in both groups. However, there was a statistically significant difference associated with puncture on the first attempt in the "device over needle with extension" group $(p=0.038)$.

Mostly nursing technicians, corresponding to $92.18 \%$ in the "device over needle with extension" group and $79.68 \%$ in the "without extension" group, performed the punctures. When correlating the punctures performed by nurses and nursing technicians and their professional experience, there was no statistically significant difference.

Regarding the mean duration of the PVA installation procedure, the group "device over needle with extension" obtained 10 minutes $(S D=3.50)$, with a minimum of four and a maximum of 22 minutes. In the "without extension" group, it corresponded to 10 minutes $(S D=3.07)$, ranging from five to 19 minutes. Considering the constituent steps of the procedure (separation of materials, explanation of the procedure to the patient, venous network evaluation, puncture and nursing annotation), there was a similarity in the mean duration time in both groups. The stage of venipuncture had the longest duration (four minutes $\mathrm{SD}=2.40$ in the "device over needle with extension" group and four minutes - SD=1.85 in the "without extension" group).

As shown in Table 2, the material cost was US\$ 7.71 (SD=2.28) in the "device over needle with extension" group and US\$ 2.66 $(S D=0.74)$ in the "without extension" group, representing the most significant value for the composition of the mean direct cost of the procedure, US\$9.37 (SD=2.79) and US\$ $4.50(S D=1.29)$, respectively. 
Table 1 - Distribution of medical diagnostic hypotheses, reasons for indicating PVA* and number of puncture attempts in the 128 patients, São Paulo, São Paulo, Brazil, 2017

\begin{tabular}{|c|c|c|c|}
\hline \multirow[b]{2}{*}{ Variables } & \multicolumn{2}{|c|}{ Device over needle } & \multirow[b]{2}{*}{$\underset{\text { value }^{\dagger}}{\boldsymbol{p}}$} \\
\hline & $\begin{array}{c}\text { With } \\
\text { extension } \\
n=64\end{array}$ & $\begin{array}{c}\text { Without } \\
\text { extension } \\
n=64\end{array}$ & \\
\hline \multicolumn{4}{|l|}{ Diagnosis } \\
\hline Cardiac insufficiency & 6 & 6 & 1.000 \\
\hline Hypertension & 25 & 23 & 0.855 \\
\hline Systemic lupus erythematosus & 4 & 6 & 0.744 \\
\hline Dyslipidemia & 4 & 6 & 0.744 \\
\hline Diabetes Mellitus & 17 & 20 & 0.697 \\
\hline Encephalopathy & 4 & 2 & 0.680 \\
\hline Pneumonia & 2 & 4 & 0.680 \\
\hline Chronic Kidney Disease & 9 & 12 & 0.634 \\
\hline Stroke & 1 & 3 & 0.619 \\
\hline Pleural effusion & 2 & 0 & 0.496 \\
\hline Infection & 8 & 4 & 0.364 \\
\hline Anemia & 12 & 7 & 0.320 \\
\hline Chronic obstructive pulmonary disease & 1 & 5 & 0.208 \\
\hline Cirrhosis & 3 & 8 & 0.206 \\
\hline Acute Kidney Failure & 4 & 0 & 0.119 \\
\hline \multicolumn{4}{|l|}{ Indication for PVA installation* } \\
\hline Painkiller administration & 18 & 22 & 0.568 \\
\hline Electrolyte replacement & 7 & 11 & 0.446 \\
\hline Hemotherapy administration & 5 & 2 & 0.440 \\
\hline Antibiotic administration & 22 & 27 & 0.467 \\
\hline Diuretic administration & 12 & 7 & 0.223 \\
\hline \multicolumn{4}{|l|}{ Puncture attempt } \\
\hline 01 attempt & 54 & 43 & 0.038 \\
\hline 02 attempt & 10 & 19 & 0.143 \\
\hline 03 attempt & 0 & 2 & 0.496 \\
\hline
\end{tabular}

Note: *PVA - peripheral venous access; $+p$ value-Chi-square test.

In the "with extension" group, the unit costs of the devices predominated (gauges \# 20 and \# 24 - US\$ 5.89; \# 22 - US\$ 5.91). They impacted the composition of total costs (33 units of gauge \# 20/ US\$ 194.37; 23 gauge \# 24/US\$ 135.47 units and 19 gauge \#22/\$ 112.29 units), besides the mean cost of the transparent film mean US\$ 0.41 (63 units/US\$ 26.17). In the "without extension" group, the most costly materials were clear film with reinforced edges (unit - US\$ 1.65/33 units/US\$ 54.33); polyvinyl two-way extension (unit - US\$ 0.67/65 units - US\$ 37.47) and devices without extension (gauges \# 20 and \# 22 unit value US\$ 0.48/82 units - US\$ 39.36).

In the "device over needle with extension" and "without extension" groups, a single device was used to ensure successful PVA puncture in most patients (84.38\% and 67.18\%). In the first group, two devices were used in ten patients. In the second, two devices were used in 14 patients and three devices in the "without extension" group in two patients.
Table 3 - Outcome distribution, up to 96 h PVA stay*, in the "device over needle with extension" and "device over needle without extension" groups, São Paulo, São Paulo, Brazil, 2017

\begin{tabular}{|c|c|c|c|}
\hline \multirow[b]{2}{*}{ Clinical outcomes } & \multicolumn{2}{|c|}{ Device over needles } & \multirow[b]{2}{*}{$\begin{array}{c}p \\
\text { value }\end{array}$} \\
\hline & $\begin{array}{c}\text { With } \\
\text { extension }\end{array}$ & $\begin{array}{l}\text { Without } \\
\text { extension }\end{array}$ & \\
\hline First day & $\mathrm{n}=64$ & $\mathrm{n}=64$ & \\
\hline Absence of phlogistic signs & 63 & 56 & 0.03 \\
\hline Pain & 0 & 4 & 0.11 \\
\hline Accidental loss & 1 & 4 & 0.36 \\
\hline Second day & $n=63$ & $n=56$ & \\
\hline Absence of phlogistic signs & 50 & 51 & 0.82 \\
\hline Pain & 5 & 0 & 0.05 \\
\hline Extravasation & 1 & 1 & 1.00 \\
\hline Phlebitis & 0 & 1 & 1.00 \\
\hline Accidental loss & 1 & 2 & 1.00 \\
\hline End of therapy & 6 & 1 & 0.20 \\
\hline Third day & $\mathrm{n}=50$ & $\mathrm{n}=51$ & \\
\hline Absence of phlogistic signs & 45 & 41 & 0.57 \\
\hline Phlebitis & 0 & 2 & 0.49 \\
\hline Accidental loss & 0 & 4 & 0.11 \\
\hline End of therapy & 5 & 4 & 0.71 \\
\hline Fourth day & $\mathrm{n}=45$ & $\mathrm{n}=41$ & \\
\hline Absence of phlogistic signs & 43 & 36 & 0.27 \\
\hline Pain & 1 & 1 & 1.00 \\
\hline Accidental loss & 1 & 3 & 0.61 \\
\hline End of therapy & 0 & 1 & 1.00 \\
\hline Everyday (96 hours) & $n=64$ & $n=64$ & \\
\hline Absence of phlogistic signs & 43 & 36 & 0.27 \\
\hline Pain & 6 & 5 & 1.00 \\
\hline Extravasation & 1 & 1 & 1.00 \\
\hline Phlebitis & 0 & 3 & 0.24 \\
\hline Accidental loss & 3 & 13 & 0.01 \\
\hline End of therapy & 11 & 6 & 0.27 \\
\hline
\end{tabular}

Regarding outcomes (Table 3), in both groups, the absence of phlogistic signs predominated on the first day, and this outcome was more prevalent in the "with extension" group, with a statistically significant difference $(p=0.033)$.

In the daily evaluation, the device losses were subtracted. Counting at 96 hours, the group "device over needle with extension" presented lower occurrence of accidental loss with significant statistical difference $(p=0.014)$.

\section{DISCUSSION}

In the present study, similarly to what was found in recent research ${ }^{(1,10-11)}$, PVA installation by predominant mid-level professionals, properly trained and experienced in performing this

Table 2 - Distribution of observations of PVA installation procedure* $(n=128)$, devices over needle "with extension" ( $n=64)$ and "without extension" ( $n=64)$ groups, according to DL cost of nursing professionals, material cost and total mean direct cost, São Paulo, São Paulo, Brazil, 2017

\begin{tabular}{|c|c|c|c|c|c|c|c|c|c|}
\hline \multirow{2}{*}{$\begin{array}{l}\text { Groups } \\
\text { Observations }\end{array}$} & \multicolumn{4}{|c|}{ Device over needle with extension } & \multicolumn{4}{|c|}{ Device over needle without extension } & \multirow[b]{2}{*}{$\begin{array}{c}p \\
\text { value }\end{array}$} \\
\hline & $\begin{array}{c}\text { Mean } \\
\text { US\$ }^{+}\end{array}$ & $\begin{array}{c}\text { Standard } \\
\text { Deviation } \\
\text { US\$ }^{+}\end{array}$ & $\underset{\mathbf{U S}^{+}}{\operatorname{Minimum}}$ & $\underset{\text { US\$ }^{+}}{\text {Maximum }}$ & $\begin{array}{l}\text { Mean } \\
\text { US\$ }^{+}\end{array}$ & $\begin{array}{c}\text { Standard } \\
\text { Deviation } \\
\text { US\$ }^{+}\end{array}$ & $\underset{\mathbf{U S}^{+}}{\text {Minimum }}$ & $\underset{\text { US\$ }^{+}}{\text {Maximum }}$ & \\
\hline $\begin{array}{l}\text { Cost of direct labor of nursing } \\
\text { professionals (US\$ }+ \text { ) }\end{array}$ & 1.66 & 0.82 & 0.71 & 5.32 & 1.84 & 0.92 & 0.92 & 5.23 & 0.31 \\
\hline Material cost (US\$ †) & 7.71 & 2.28 & 6.67 & 13.80 & 2.66 & 0.74 & 1.71 & 4.29 & $<0.001$ \\
\hline Total mean direct cost (US\$ †) & 9.37 & 2.79 & 7.38 & 19.12 & 4.50 & 1.29 & 2.74 & 8.99 & $<0.001$ \\
\hline
\end{tabular}


procedure, predominated. In the Brazilian reality, this result was expected considering that mid-level professionals represent the largest quantity in the composition of the nursing team. In addition, considering the particularities of work processes, nurses often perform indirect patient care interventions, managing resources to enable the provision of health services. They prioritize the execution of direct care interventions in cases of patients with higher complexity/severity profiles.

The mean age and the most prevalent medical diagnostic hypotheses among the observed patients also presented similarities with results obtained in other national and international studies. The mean showed that they were patients near the end of adulthood ${ }^{(1,10,12-13)}$, with chronic diseases, especially hypertension and $\mathrm{DM}^{(1,10)}$. The most frequent indication for PVA establishment was for antibiotic administration, which is in agreement with the literature ${ }^{(6,14-15)}$.

Regarding the successful PVA establishment in the first puncture, a statistically significant difference was found in the "device over needle with extension" group compared to the "device over needle without extension" group.

There were randomized controlled trial conducted in clinical and surgical units of a large university hospital ${ }^{(1)}$, two prospective randomized controlled trials, one conducted in clinical and surgical units of a university hospital( ${ }^{(6)}$ and another in an emergency room of a university-affiliated urban community hospital ${ }^{(11)}$. These studies found favorable results regarding the use of the needle with extension in the first puncture attempt.

The importance of establishing PVA in the first puncture attempt is emphasized in order to make the procedure less painful for the patient ${ }^{(16)}$, to avoid damage to the venous network due to multiple punctures, to prevent interruption of intravenous therapy ${ }^{(17)}$ and direct the rational consumption of resources preventing the increase of costs.

Regarding the size of the devices, there was a predominance of gauges \# 20, \# 22 and \# 24, due to difficult access venous network, as also verified in other studies ${ }^{(1,10,12,18)}$. The choice of using a smaller gauge device, through careful prior evaluation of the venous network, is a decisive factor for the successful PVA establishment in the first puncture attempt. However, success in the first puncture attempt is more related to the lower level of pain referred by the patient, by numerical scale, than to the device gauge ${ }^{(16)}$.

In this study, the mean duration of the PVA installation procedure in the "with extension" and "without extension" groups was similar. Venous puncture was the stage that presented the longest duration in both groups. Despite recurring searches in different databases, no research was found to indicate the timed PVA establishment time.

Only one study was found reporting estimated duration ${ }^{(6)}$. However, the authors used a mean puncture time, without indicating the procedure steps that were included, to calculate labor cost and data from another hypothetical cohort study that estimated the cost-effectiveness of devices with and without stabilization platform ${ }^{(19)}$.

The mean direct cost of installing PVA was significantly higher in the "device over needle with extension" group compared to the "device over needle without extension" group. Similar results to research conducted in Japan ${ }^{(17)}$ and Spain ${ }^{(6)}$ evaluated the costs of puncture with and without extension devices. In both groups, similar to another Brazilian study ${ }^{(19)}$, the cost of materials corresponded to the variable with the greatest financial repercussion.

In the group "device over needle with extension", the unit costs of the devices were the most important for the composition of the mean direct cost. In the "device over needle without extension" group, the reinforced edge transparent film whose indication, in the teaching and research hospital field of study, has been for central catheters with weekly exchange routine, corresponding to the item with the highest unit cost.

Intentional use of an institutionally non-standardized material for the fixation of the intravascular device indicates the influence of clinical experience and nursing professionals' experience as a support for the decision-making process regarding the choice and rational use of available resources. Transparent film is a protective factor to prevent the occurrence of PVA-related adverse events ${ }^{(20)}$. There is evidence that the effectiveness of the reinforced transparent film is superior to that of traditional film (without reinforced edges) (21).

Decision-making regarding the use of both intravascular device and other materials used for safe PVA establishment and maintenance need to be based on both the clinical experience of professionals and the best available evidence. In this perspective, a study ${ }^{(17)}$ showed that although the cost of the first puncture is higher as the use of the device with extension, costs are significantly higher when using devices without extension that presented higher frequency of new punctures resulting from unplanned replacements.

Regarding length of stay, a statistically significant difference was observed between punctures with absence of phlogistic signs in the "device over needle with extension" group compared to the "without extension" group. It is reiterated that, as recommended by the CDC, venous access should last up to 96 hours $^{(4)}$. Removal of the device, due to any complication, causes some harm to the patient, which may range from performing a new procedure to prolonging the hospitalization time for phlebitis treatment.

According to the Infusion Nurses Society ${ }^{(5)}$, phlebitis is a frequent complication due to an inflammatory process that affects the intimate layer of the vein and may cause pain, edema, local erythema and heat, in addition to the appearance of a palpable fibrous cord. It may be mechanical, related to size of gauge; chemistry related to infusion of irritant/vesicant solution; or infectious when there is contamination due to failure of the puncture technique. When the patient needs an intervention beyond the therapeutic plan due to his clinical situation, and his hospitalization is prolonged due to phlebitis, there is an adverse event considered serious ${ }^{(20)}$.

Studies that analyzed the occurrences associated with PVA residence time indicated, as the most relevant, the presence of phlebitis $^{(1,10,14-15,18,20,22)}$, as well as pain ${ }^{(18)}$, resulting in withdrawal early access, and accidental removal ${ }^{(1,20)}$.

In this study, the phlebitis scale ${ }^{(5)}$ was used to classify the outcomes, and it was found that pain reports, without the presence of other phlogistic signs, were associated with catheter positioning in joint sites, thus causing greater discomfort to the patient. Pain, extravasation, phlebitis and accidental loss generated early 
withdrawal in $16 \%$ of cases in the "device over needle with extension" group. In 34\% in the "without extension" group, there was no statistically significant difference regarding the occurrence of phlebitis between the cases of these groups. This favorable result was also obtained in a recent study in Japan ${ }^{(17)}$. This research, when evaluating the outcomes related to PVA with the use of devices with and without extension, associated the decrease of the need for new puncture, caused by accidental loss, when using the device with extension.

In care practice, as previously mentioned, nursing professionals are responsible for the insertion and maintenance of PVA to enable IVT safely and efficiently. However, the successful completion of venipuncture and adequate access maintenance, in addition to being directly related to the technical and scientific competence of nursing professionals, depends on the material resources provided by the health institution.

In this sense, available resources, in adequate quantity and quality, may result in favorable outcomes (absence of adverse events, end of intravenous therapy within the recommended time, among others). Otherwise, there will be increased costs related to resources consumed for the management of an adverse event and risks. They could be minimized/avoided, the occurrence of intangible costs for the patient that will affect the evolution of his clinical condition and the trust he placed in the professionals and the health institution.

\section{Study limitations}

Limitations of this study in a single unit and the fact that care associated with PVA maintenance.

\section{Contributions to nursing, health or public policy}

The timing of the total time of PVA establishment, using devices with needle with and without extension, represents an advance in the knowledge about the subject. This is particularly true when demonstrating that the type of device was not associated with a significant statistical difference in the DL cost composition of the professionals involved in the procedure. Statistical tests showed that the use of the "device over needle with extension", despite its higher mean direct cost, was more effective in favoring adequate PVA residence time.

\section{CONCLUSIONS}

PVA establishment in patients in the "device over needle with extension" group had a total mean direct cost 2.9 times higher than the "device over needle without extension" group, and the material cost in both groups was the variable with most significant value for its composition. In the first 24 hours, absence of phlogistic signs predominated in both groups and was statistically significant in the "device over needle with extension" group. Considering the 96 hours of stay, the group "device over needle with extension" presented lower occurrence of accidental loss.

\section{FUNDING}

The present work was carried out with the support of the Brazilian Council for Scientific and Technological Development (CNPq - Conselho Nacional de Desenvolvimento Científico e Tecnológico).

\section{REFERENCES}

1. Danski MTR, Johann DA, Vayego SA, Oliveira GRL, Lind J. Complications related to the use of peripheral venous catheters: a randomized clinical trial. Acta Paul Enferm. 2016;29(1):84-92. doi.: 10.1590/1982-0194201600012

2. Ministério da Saúde. Agência Nacional de Vigilância Sanitária - ANVISA. Medidas de Prevenção de Infecção relacionada à Assistência à Saúde [Internet]. 2017 [cited 2017 Oct 15]. Available from: http://portal.anvisa.gov.br/documents/33852/3507912/Caderno+4+-+Medid as+de+Preven $\%$ C3\%A7\%C3\%A3o+de+Infec\%C3\%A7\%C3\%A3o+Relacionada+\%C3\%A0+Assist\%C3\%AAncia+\%C3\%A0+Sa\%C3\%BAde/ a3f23dfb-2c54-4e64-881c-fccf9220c373

3. Lima AFC, Castilho V, Baptista CMC, Rogenski NMB, Rogenski KE. Direct cost of dressings for pressure ulcers in hospitalized patients. Rev Bras Enferm. 2016;69(2):290-7. doi: 10.1590/0034-7167.2016690212i

4. O'Grady NP, Alexander M, Burns LA, Dellinger EP, Garland J, Heard SO, et al. Centers for Disease Control and Prevention. Guidelines for the prevention of intravascular catheter-related infections [Internet]. 2011 [cited 2017 Dec 9]. Available from: https://www.cdc.gov/hai/pdfs/ bsi-guidelines-2011.pdf

5. Gorski L, Hadaway L, Hagle M, Goldrick M,Doellman. D. Infusion Nurses Society. infusion nursing standards of practice. J Infus Nurs [Internet]. 2016 [cited 2017 Oct 9];39(1S). Available from: http://source.yiboshi.com/20170417/1492425631944540325.pdf

6. López JLG, Vilela AA, Palacio EF, Corral JO, Martí CB, Portal PH. Indwell times, complications and costs of open vs closed safety peripheral intravenous catheters: a randomized study. J Hosp Infect. 2014;86(2):117-26. doi: 10.1016/j.jhin.2013.10.008

7. Martins E. Contabilidade de custos. 10th Edition. São Paulo: Atlas, 2010.

8. Lima AFC, Castilho V. Body mobilization for prevention of pressure ulcers: direct labor costs. Rev Bras Enferm. 2015;68(5):930-6. doi: 10.1590/0034-7167.2015680523i

9. Lima AFC. Direct costs of integrated procedures of conventional hemodialysis performed by nursing professionals. Rev Latino-Am Enfermagem. 2018;26:e2944. doi: 10.1590/1518-8345.1812.2944

10. Enes SMS, Opitz SP, Faro ARMC, Pedreira MLG. Phlebitis associated with peripheral intravenous catheters in adults admitted to hospital in the Western Brazilian Amazon. Rev Esc Enferm USP. 2016;50(2):263-71. doi: 10.1590/S0080-623420160000200012 
11. Moayedi S, Witting M, Hirshon JM, Georde N, Burke A, Schenkel S. Prospective, randomized controlled comparison of a flash-tip catheter and a traditional intravenous catheter in an urban emergency department. J Vasc Access. 2018;1-5. doi: 10.1177/1129729817747530

12. Abdul-Hak CK, Barros AF. Incidência de flebite em uma unidade de clínica médica. Texto Contexto Enferm, 2014;23(3):633-8. doi: 10.1590/0104-07072014000900013

13. Xu L, Hu Y, Huang X, Fu J, Zhang J. Clinacally indicated replacement versus routine replacement os peripheral venous catheters in adults. A nonblinded, cluster-randomized trial in China. Int J Nurs Pract. 2017;23(6). doi: 10.1111/ijn.12595

14. Tan YH, Tai WL, Sim C, Ng HL. Optimising peripheral venous catheter usage in general inpatient ward: a prospective observational study. J Clin Nurs. 2016;26(1-2):133-9. doi: 10.1111/jocn.13451

15. Pasalioglu KB, Kaya H. Catheter indwell time and phlebitis development during peripheral intravenous catheter administration. Pak J Med Sci [Internet]. 2014[cited 2017 Oct 9];30(4):725-30. Available from: https://www.ncbi.nlm.nih.gov/pubmed/25097505

16. Van Loon FHJ, Puijn LAPM, Aarle WH, Daele ATMD, Bouwman ARA. Pain upon inserting a peripheral intravenous catheter: Size does not matter. J Vasc Access. 2017;30(4):725-30. doi: 10.1177/1129729817747531

17. Tamura N, Hagimoto K, Matsuo A, Ozawa Y, Takahashi M, Yokokawa S, et al. Unfavorable peripheral intravenous catheter replacements can be reduced using an integrated closed intravenous catheter system. J Vasc Access. 2014;15(4):257-63. doi: 10.5301/jva.5000245

18. Tanabe H, Murayama R, Yabunaka K, Oe M, Takahashi T, Komiyama C et al. Low-angled peripheral intravenous catheter tip placement decreases phlebitis. J Vasc Access. 2016;17(6):542-7. doi: 10.5301/jva.5000601

19. Mensor LL, Aguiar DG, Sousa CPR. Cost-effectiveness of peripheral catheters with integrated stabilization platform under the perspective of hospitals in Brazil. J Bras Econ Saude [Internet]. 2016 [cited 2017 Feb 13];8(1):16-23. Available from: http://files.bvs.br/ upload/S/2175-2095/2016/v8n1/a5477.pdf

20. Miliani K, Taravella R, Thillard D, Chauvin V, Martin E, Edouard S et al. Peripheral Venous Catheter-related adverse events: evaluation from a multicenter epidemiological study in France (the CATHEVAL Project). Plos One. 2017;12(1):e0168637. doi: 10.1371/journal.pone.0168637

21. Marsh N, Webster J, Flynn J, Mihala G, Fraser J, Rickard CM. Securement methods for peripheral venous catheters to prevent failure: a randomized controlled pilot trial. J Vasc Access. 2015;16 (3):237-44. doi: 10.5301/jva.5000348

22. Helm RE, Klausner JD, Klemperer JD, Flint LM, Huang E. Accepted but unacceptable: peripheral IV catheter failure. J Infus Nurs. 2015;38(3):189-203. doi: 0.1097/NAN.0000000000000100 